1 Sero-prevalence of anti-SARS-CoV-2 antibodies in Chattogram Metropolitan Area,

\title{
2 Bangladesh
}

3 Jahan Ara ${ }^{1}$, Md. Sirazul Islam²,3, Md. Tarek Ul Quader ${ }^{4}$, Anan Das ${ }^{1}$, F. M. Yasir Hasib ${ }^{2,5}$,

4 Mohammad Saiful Islam ${ }^{6}$, Tazrina Rahman ${ }^{7}$, Seemanta Das ${ }^{1}$, M.A. Hassan Chowdhury ${ }^{8}$, Goutam

5 Buddha Das ${ }^{3,9}$, and Sharmin Chowdhury ${ }^{1,2,3}$.

$6 \quad{ }^{1}$ One Health Institute, Chattogram Veterinary and Animal Sciences University, Khulshi-4225,

7 Chattogram, Bangladesh;

$8{ }^{2}$ Department of Pathology and Parasitology, Faculty of Veterinary Medicine, Chattogram

9 Veterinary and Animal Sciences University, Khulshi-4225, Chattogram, Bangladesh;

$10{ }^{3}$ COVID-19 Detection Laboratory, Chattogram Veterinary and Animal Sciences University,

11 Khulshi-4225, Chattogram, Bangladesh;

$12{ }^{4}$ Department of Anesthesiology and ICU, Chittagong Medical College Hospital, Chattogram, 13 Bangladesh;

14 5epartment of Infectious Diseases and Public Health, City University of Hong Kong, Hong Kong 15 SAR;

$16{ }^{6}$ Department of Emergency and Accident, Imperial Hospital Limited, Chattogram, Bangladesh;

$17{ }^{7}$ Department of Microbiology and Virology, Chittagong Medical College, Chattogram, 18 Bangladesh;

$19{ }^{8}$ Department of Medicine, Chittagong Medical College, Chattogram, Bangladesh;

$20{ }^{9}$ Department of Animal Science and Nutrition, Chattogram Veterinary and Animal Sciences

21 University, Khulshi-4225, Chattogram, Bangladesh. 
medRxiv preprint doi: https://doi.org/10.1101/2022.02.09.22270717; this version posted February 9, 2022. The copyright holder for this preprint (which was not certified by peer review) is the author/funder, who has granted medRxiv a license to display the preprint in perpetuity.

It is made available under a CC-BY 4.0 International license.

\section{Sharmin Chowdhury, PhD}

25 Director, One Health Institute, Chattogram Veterinary and Animal Sciences University, Khulshi,

26 Chattogram-4225.

27 E-mail: sharminchowdhury@cvasu.ac.bd

\section{Abstract}

Background: Seroprevalence studies of coronavirus disease 2019 (COVID-19) assess the degree of undetected transmission in the community. Different groups, such as healthcare workers (HCWs), garment workers, and others, are deemed vulnerable due to their workplace hazards and immense responsibility.

Purpose: The present study was conducted to estimate the seroprevalence of anti-SARS-CoV-2 antibody $(\operatorname{IgG})$ and its association with different explanatory variables. Further, the antibody was quantified to assess the increasing or decreasing trend over different intervention periods and

37 according to other factors.

Methodology: This cross-sectional study observed health workers - doctor, nurse, hospital staff, etc. in and outpatients (non-COVID-19) and garments workers of Chattogram metropolitan area (CMA, N=748) from randomly selected six government and private hospitals and two garment

41 factories. Study subjects were included upon written consent, fulfilling specific inclusion criteria.

42 Venous blood was collected following standard aseptic methods. Qualitative and quantitative ELISA was used to identify and quantify antibodies (IgG) in serum samples. Descriptive, 44 univariable, and multivariable statistical analysis was performed.

45 Results: Overall seroprevalence was estimated as $66.99 \%$ (95\% CI: $63.40 \%-70.40 \%$ ).

46 Seroprevalence among HCWs, in and outpatients, and garments workers were $68.99 \%$ (95\% CI: 
medRxiv preprint doi: https://doi.org/10.1101/2022.02.09.22270717; this version posted February 9, 2022. The copyright holder for this preprint (which was not certified by peer review) is the author/funder, who has granted medRxiv a license to display the preprint in perpetuity.

It is made available under a CC-BY 4.0 International license .

63.8\%-73.7\%), $81.37 \%$ (95\% CI: 74.7\%-86.7\%), and $50.56 \%$ (95\% CI: $43.5 \%-57.5 \%)$, respectively. Seroprevalence was $44.47 \%(95 \%$ CI: $38.6 \%-50.4 \%)$ in the non-vaccinated population while it was significantly $(p<0.001)$ higher in the population receiving the first dose (61.66 \%, 95\% CI: 54.8\%-68.0\%) and both (first and second) doses of vaccine (100\%, 95\% CI: 98.4\%-100\%). The mean titer of the antibody was estimated as $255.46 \mathrm{DU} / \mathrm{ml}$ and $159.08 \mathrm{DU} / \mathrm{ml}$ in the population with both doses and one dose of vaccine, respectively, compared to $53.71 \mathrm{DU} / \mathrm{ml}$ of the unvaccinated population. A decreasing trend in the titer of antibodies with increasing time after vaccination was observed.

Conclusions: Seroprevalence and mean antibody titer varied according to different factors in this study. The second dose of vaccine significantly increased the seroprevalence and titer, which decreased to a certain level over time. Although antibody was produced following natural infection, the mean titer was relatively low compared to antibody after vaccination. This study emphasizes the role of the vaccine in antibody production. Based on the findings, interventions like continuing extensive mass vaccination of the leftover unvaccinated population and bringing the mass population with a second dose under a third dose campaign might be planned.

Keywords: Seroprevalence, anti-SARS-CoV-2 antibody, antibody titer, IgG

\section{Introduction}

Chattogram, the port city of Bangladesh, is classified as a high-risk zone for SARS-CoV-2 contact transmission and is one of the most crowded economic and trading centers [1]. On April 3, 2020, Chattogram city witnessed its first Coronavirus Disease 2019 (COVID-19) positive case [2], followed by the first death on 9 April [3]. The disease can manifest itself in various ways, from 
medRxiv preprint doi: https://doi.org/10.1101/2022.02.09.22270717; this version posted February 9, 2022. The copyright holder for this preprint (which was not certified by peer review) is the author/funder, who has granted medRxiv a license to display the preprint in perpetuity.

It is made available under a CC-BY 4.0 International license.

asymptomatic and minor upper respiratory symptoms to severe pneumonia and acute respiratory distress syndrome [4]. While nucleic acid amplification, such as polymerase chain reaction (PCR), is the gold standard for diagnosing acute SARS-CoV-2 infection and is widely recommended, the antibody-based approach improves diagnosis accuracy by capturing asymptomatic testing and recovered infections [5].

During an infectious disease outbreak, seroprevalence investigations are crucial in revealing undetected infection in the population and preventing post-pandemic reappearance [6]. Determining the actual burden of infection is also vital for epidemic forecasting and response planning. Seroprevalence studies are potent in identifying the number of undiagnosed missing cases with mild or no symptoms or who cannot undergo testing that may contribute significantly to the transmission [7-11]. Further, seroprevalence studies estimate the susceptible population in a community. A current investigation discovered that up to $23 \%$ of the patients diagnosed with COVID-19 from December 2020 to February 2021 in Bangladesh were asymptomatic [12]. Thus, antibody testing could be crucial to determine the actual SARS-CoV-2 exposure rates since PCR only identifies the viral nucleic acid in individuals with existing symptoms [13].

According to numerous research, seropositivity fluctuates considerably depending on parameters such as location and time [7, 14]. Antibody titers reach their peak one month after the onset of symptoms, and their levels are directly proportional to the severity of the illness [15]. Titers continue to fall after that, with IgM and IgA titers falling fast and IgG titers falling more slowly [16]. However, a greater understanding of antibody responses to SARS-CoV-2 after natural infection might aid in the development of more successful vaccination strategies in the future. Bangladesh started administering COVID-19 vaccinations on January 27, 2021, and mass immunization commenced on February 7, $2021[\mathbf{1 7}, \mathbf{1 8}]$. As of December 21, 2021, 50.27\% of the 
medRxiv preprint doi: https://doi.org/10.1101/2022.02.09.22270717; this version posted February 9, 2022. The copyright holder for this preprint (which was not certified by peer review) is the author/funder, who has granted medRxiv a license to display the preprint in perpetuity.

It is made available under a CC-BY 4.0 International license .

target population had received the first dose, and $34.60 \%$ received the second dose [19]. Bangladesh has already started administering third doses to senior persons aged 60 and up, people with comorbidities, and frontline workers. [20]. According to a web-based anonymous crosssectional survey conducted among the general Bangladeshi population between January 30 and February 6, 2002, 61.16\% of respondents were inclined to accept/take the COVID-19 vaccine [21]. However, vaccination coverage and seroprevalence among the general public must be investigated nationwide to know the herd immunity.

In the COVID-19 pandemic, HCWs are facing immense challenges worldwide. Occupational exposures among HCWs have been documented in numerous nations as worrying [22]. Likewise, COVID-19 has had a significant impact on the healthcare system of Bangladesh. According to the latest data from the Bangladesh Medical Association, between March 8, 2020, and November 11, 2021, 9455 HCWs, including physicians, nurses, and other staff, were infected with COVID-19, as well as 188 doctors died as a result [23]. Front liners directly involved in diagnosing, treating, and caring for COVID-19 patients are at risk of physical and psychological distress [24-29]. Similarly, workers in the garment industry confront different problems in the workplace all around the world. According to the Bangladesh Garment Manufacturers and Exporters Association (BGMEA), 4500 garment companies employ over 4.5 million people or nearly 2.5 percent of the country's entire population [30]. The bulk of the industries operate with limited space, making it challenging to enforce physical distancing norms [31]. SARS-CoV-2 transmission might be exacerbated by crowded workplaces, transportation, and lack of physical distancing [32]. Hence, it is necessary to put in place measures including risk management in the workplace, vulnerable employee care, the development of an occupational surveillance system, and vaccination policy 
medRxiv preprint doi: https://doi.org/10.1101/2022.02.09.22270717; this version posted February 9, 2022. The copyright holder for this preprint (which was not certified by peer review) is the author/funder, who has granted medRxiv a license to display the preprint in perpetuity.

It is made available under a CC-BY 4.0 International license.

115 administration to address the COVID-19 issues $[\mathbf{3 3}, \mathbf{3 4}]$. Thus, knowing the true seroprevalence

116 both in the risk groups and community might assist in planning interventions efficiently.

117 In this study, we reported population-based SARS-CoV-2 seropositivity among HCWs, indoor and 118 outdoor patients of various government and private hospitals, and garment workers of CMA, as 119 determined by enzyme-linked immunosorbent assay (ELISA). Moreover, we measured the 120 antibody titer, and both outcomes (seropositivity and antibody titer) were tested to know the 121 association of different factors.

\section{Materials and Methods}

\section{Study design and setting}

124 From February to September 2021, we conducted a cross-sectional population-based study among 125 HCWs (e.g., doctors, nurses, hospital staff, ward boy, and cleaner), garment workers, and indoor 126 and outdoor patients (non-COVID-19) of six government and private hospitals each, and two 127 garment factories in CMA. All hospitals belonging to the study area were stratified according to 128 their affiliation status; government and private. From each stratum, six hospitals were randomly 129 selected. Sample size was calculated considering the following parameter: 0.65 proportion, $5 \%$ margin of error, 95\% confidence limit and design effect 2 . Each organization's human resources

131 department provided a list of personnel. Following a simple random sampling technique, samples 132 were collected from a total of 748 respondents.

133 We interviewed participants to collect information after receiving written consent. Answering a 134 questionnaire and taking blood to test SARS CoV-2 antibodies were part of the study procedure. 135 Our study followed a World Health Organization protocol for population-level COVID-19 136 antibody testing [35]. The questionnaire included sociodemographic details and factors 
medRxiv preprint doi: https://doi.org/10.1101/2022.02.09.22270717; this version posted February 9, 2022. The copyright holder for this preprint (which was not certified by peer review) is the author/funder, who has granted medRxiv a license to display the preprint in perpetuity.

It is made available under a CC-BY 4.0 International license .

137 hypothesized to be associated with seropositivity. Participants were included in the study based on

138 several inclusion criteria.

139 Inclusion criteria:

140

141

142

143

144

145

146

147

148

149

150

151

152 until serological investigation.

\section{Serological test examination}

154 Antibody was determined by a commercial qualitative assay using COVID-19 IgG ELISA test

155 (Beijing Kewei Clinical Diagnostic Reagent Inc., China; Ref: 601340) as per the manufacturer's

156 instructions. The assay is an enzyme-linked immunoassay (ELISA) that detects IgG against the

157 SARS-CoV-2. An index (Absorbance/Cutt-off) of $<1$ was interpreted as negative, 0.9 to 1.1 as 
medRxiv preprint doi: https://doi.org/10.1101/2022.02.09.22270717; this version posted February 9, 2022. The copyright holder for this preprint (which was not certified by peer review) is the author/funder, who has granted medRxiv a license to display the preprint in perpetuity.

It is made available under a CC-BY 4.0 International license .

158 borderline (retesting of these specimens in duplicates was done to confirm results), and $\geq 1$ index

159 as positive. Per the manufacturer, the sensitivity and specificity of the assay for IgG are $93.8 \%$ and 97.3\%, respectively. Positive and negative controls were included in all assay batches. Repeated testing using the same specimen yielded the same interpretation.

162 The concentration of IgG antibodies was determined by SARS-CoV-2 S1-RBD IgG (DiaSino ${ }^{\circledR}$

163 Laboratories Co., Ltd. Zhengzhou, China, Ref: DS207704), which is based on enzyme-linked 164 immunoassay for the quantitative detection of IgG antibodies. The assay's sensitivity and 165 specificity for IgG quantification, according to the manufacturer, are $98.41 \%$ and $98.02 \%$, 166 respectively. Quantitative results were calculated as a ratio of the extinction of the control or tested

167 specimen over the extinction of the calibrator. Results were reported in standardized units for the 168 quantitative kits that included six calibrators to quantify the antibody concentration (i.e., DiaSino 169 units $/ \mathrm{mL}$ ). A value of $<10 \mathrm{DU} / \mathrm{mL}$ was considered negative, and values $>10 \mathrm{DU} / \mathrm{mL}$ were 170 positive.

\section{Data management}

172 The linearity of the quantitative variables was evaluated by categorizing them into four categories

173 using quartiles as cut-off values. Logistic regression analysis was conducted on the categorized

174 variables, and parameter estimates were observed for an increasing or decreasing trend. In case of 175 linear increase or decrease in the parameter estimates, linearity in the quantitative variable was 176 assumed and used without modification. In the case of nonlinearity, a quartile was used to 177 categorize it. However, some quantitative variables were categorized considering research interest. 178 For instance, the number of days between the first dose of vaccine and quantification of antibody 179 titer was categorized as 'after one month' and 'after two months' and between the second dose of 180 vaccine and quantification of antibody titer was categorized as 'after two months', 'after four 
medRxiv preprint doi: https://doi.org/10.1101/2022.02.09.22270717; this version posted February 9, 2022. The copyright holder for this preprint (which was not certified by peer review) is the author/funder, who has granted medRxiv a license to display the preprint in perpetuity.

It is made available under a CC-BY 4.0 International license.

months' and 'after six months'. The number of days between the vaccination and the antibody titer was achieved from the date of vaccination and sample collection. The prevalence estimates were adjusted with the test kit performance (sensitivity and specificity), and the adjusted prevalence was denoted as true prevalence.

\section{Data analysis}

In the study period, a total of 748 qualitative and quantitative test results were included in the analysis. To evaluate the correlation and collinearity in the categorical and quantitative variables, Cramer's V test, Spearman correlation coefficient, Chi-square test, t-test or ANOVA, where appropriate, was used. Variables with a significant association or a Spearman correlation coefficient above 0.4 were regarded as correlated. The effects of different potential explanatory variables on the binary outcome - presence/absence of anti-SARS-CoV-2 antibody, was evaluated using univariable and followed by multivariable logistic regression models. To select the final multivariable model, all variables with a significant $p$-value in the univariable models were included in a model and a manually conducted backward selection strategy was followed by deleting one variable at a time with the highest P-value. Interactions between all explanatory variables ( 2 ways) were evaluated in the final model. Effect of variables on the mean titer of the antibody was assessed by t-test and one way ANOVA. P-values $<0.05$ were considered as significant throughout the analysis. STATA-IC 13 (StataCorp, California, USA) and GraphPad Prism 7.00 for Windows (GraphPad Software, La Jolla, California, USA) were used for statistical analyses and visualization.

\section{Ethical approval and informed consent}


medRxiv preprint doi: https://doi.org/10.1101/2022.02.09.22270717; this version posted February 9, 2022. The copyright holder for this preprint (which was not certified by peer review) is the author/funder, who has granted medRxiv a license to display the preprint in perpetuity.

It is made available under a CC-BY 4.0 International license.

202 Institutional ethical approval was taken from the authorized committee of Chattogram Veterinary

203 and Animal Sciences University (CVASU), Bangladesh [CVASU/Dir(R\&E) EC/2020/212(1)].

\section{Results}

\section{Sero-prevalence of SARS-CoV-2 infection}

206 SARS-CoV-2 IgG antibodies were detected in 498 (66.99\%) of 748 individuals (Table 1).

207 Prevalence of anti-SARS-CoV-2 antibody (IgG) in different donor types along with vaccination 208 percentage is shown in Figure 1.

Table 1: Prevalence estimation in CMA

\begin{tabular}{|c|c|c|c|c|}
\hline $\begin{array}{l}\text { Anti-SARS CoV-2 } \\
\text { antibody }\end{array}$ & $\begin{array}{l}\text { Total } \\
\text { population }\end{array}$ & $\begin{array}{l}\text { Unadjusted } \\
\text { seroprevalence, } \\
\%(95 \% \text { CI })\end{array}$ & $\begin{array}{l}\text { Test } \\
\text { performance } \\
\text { adjusted } \\
\text { seroprevalence } \\
\%(95 \% \mathrm{CI})\end{array}$ & $\begin{array}{l}\text { Known } \\
\text { positives (RT- } \\
\text { qPCR positive) } \\
(\%)\end{array}$ \\
\hline Present & 498 & $\begin{array}{l}66.58 \quad(63.1- \\
70.0)\end{array}$ & $\begin{array}{l}66.99 \quad(63.40- \\
70.40)\end{array}$ & $91(80.53)$ \\
\hline Absent & 250 & $\begin{array}{l}33.42 \quad(30.1- \\
36.9)\end{array}$ & $\begin{array}{l}32.60 \quad(29.20- \\
36.19)\end{array}$ & $22(19.47)$ \\
\hline
\end{tabular}


medRxiv preprint doi: https://doi.org/10.1101/2022.02.09.22270717; this version posted February 9, 2022. The copyright holder for this preprint (which was not certified by peer review) is the author/funder, who has granted medRxiv a license to display the preprint in perpetuity.

It is made available under a CC-BY 4.0 International license .

212 Figure 1: Prevalence of anti-SARS-CoV-2 antibody (IgG) in different donor types along with

213 vaccinated percent.

\section{Characteristics of study participants}

216 From February -September 2021, we enrolled 748 CMA service providers (362 HCWs, 205

217 garments workers, 179 indoor/outdoor patients). Among them, 27.48\% were garment workers, 150

218 (20.11\%) hospital staff, 145 (19.44\%) doctors, $148(19.84 \%)$ outdoor patients, 67 (8.98\%) nurses,

219 and $31(4.16 \%)$ indoor patients. The majority $(n=507 ; 67.96 \%)$ were males. In the total population, vaccine, and $231(30.97 \%)$ received both doses of the vaccine. The responses regarding contact

Table 2: Baseline characteristics of study participants

\begin{tabular}{|l|l|l|l|l|}
\hline Variables & Level & Total & Known & Asymptomatic \\
& & population & positives & \\
& & & RT-qPCR & \\
& & & positive) & \\
\hline Donor type & Doctor & $145(19.44)$ & $40(35.40)$ & $85(16.13)$ \\
\cline { 2 - 5 } & Nurse & $67(8.98)$ & $19(16.81)$ & $43(8.16)$ \\
\cline { 2 - 6 } & Hospital staff & $150(20.11)$ & $27(23.89)$ & $109(20.68)$ \\
\cline { 2 - 5 } & Indoor patient & $31(4.16)$ & $2(1.77)$ & $26(4.93)$ \\
\hline
\end{tabular}




\begin{tabular}{|c|c|c|c|c|}
\hline & Outdoor patient & $148(19.84)$ & $21(18.58)$ & $109(20.68)$ \\
\hline & $\begin{array}{l}\text { Garments } \\
\text { worker }\end{array}$ & $205(27.48)$ & $4(3.54)$ & $155(29.41)$ \\
\hline Gender & Male & $507(67.96)$ & $73(65.18)$ & $362(68.69)$ \\
\hline & Female & $239(32.04)$ & $39(34.82)$ & $165(31.31)$ \\
\hline Age (year) & 19 to 29 & $201(26.91)$ & $15(13.27)$ & $149(28.27)$ \\
\hline & 30 to 35 & $184(24.63)$ & $30(26.55)$ & $123(23.34)$ \\
\hline & 36 to 44 & $180(24.10)$ & $34(30.09)$ & $123(23.34)$ \\
\hline & 45 to 84 & $182(24.36)$ & $34(30.09)$ & $132(25.05)$ \\
\hline Vaccination & No & $292(39.14)$ & $11(9.82)$ & $222(42.13)$ \\
\hline & Only $1^{\text {st }}$ dose & $223(29.89)$ & $38(33.93)$ & $153(29.03)$ \\
\hline & Both doses & $231(30.97)$ & $63(56.25)$ & $152(28.84)$ \\
\hline $\begin{array}{l}\text { Days passed after } 1^{\text {st }} \\
\text { dose of vaccine }\end{array}$ & 14 to 30 days & $45(24.06)$ & $8(25.81)$ & $\begin{array}{l}30(23.08 ; 16.1- \\
31.3)\end{array}$ \\
\hline & 31 to 60 days & $142(75.94)$ & $23(74.19)$ & $100(76.92)$ \\
\hline Days passed after & 14 to 60 days & $19(8.26)$ & $6(9.38)$ & $12(8.00)$ \\
\hline $2^{\text {nd }}$ dose vaccine & 61 to 120 days & $86(37.39)$ & $20(31.25)$ & $60(40.00)$ \\
\hline & 120 to 180 days & $125(54.35)$ & $37(59.38)$ & $78(52.00)$ \\
\hline Days between PCR & 21 to 60 days & - & $17(15.60)$ & - \\
\hline test and antibody & 61 to 120 days & - & $16(14.68)$ & - \\
\hline test & $\begin{array}{l}121 \text { to } 180 \text { days } \\
\text { months }\end{array}$ & - & $23(21.10)$ & - \\
\hline & $>180$ days & - & $53(48.62)$ & - \\
\hline
\end{tabular}


medRxiv preprint doi: https://doi.org/10.1101/2022.02.09.22270717; this version posted February 9, 2022. The copyright holder for this preprint (which was not certified by peer review) is the author/funder, who has granted medRxiv a license to display the preprint in perpetuity.

It is made available under a CC-BY 4.0 International license .

\begin{tabular}{|l|l|l|l|l|}
\hline \multirow{2}{*}{ Contact with } & Yes & $342(47.17)$ & $79(71.17)$ & $230(45.19)$ \\
\cline { 2 - 5 } & No & $307(42.34)$ & $17(15.32)$ & $232(45.58)$ \\
\cline { 2 - 5 } & Don't know & $76(10.48)$ & $15(13.51)$ & $47(9.23)$ \\
\hline Family member & 1 to 3 & $186(26.23)$ & $31(29.52)$ & $130(25.79)$ \\
\cline { 2 - 5 } Taking & 4 to 6 & $443(62.48)$ & $64(60.95)$ & $321(63.69)$ \\
\cline { 2 - 5 } immunosuppressive & $\geq 7$ & $80(11.28)$ & $10(9.52)$ & $53(10.52)$ \\
\cline { 2 - 5 } drugs & No & $15(2.13)$ & $7(6.42)$ & $8(1.63)$ \\
\hline Comorbidities & Yes & $688(97.87)$ & $102(93.58)$ & $484(98.37)$ \\
\cline { 2 - 5 } & No & $412(67.65)$ & $64(62.75)$ & $132(31.29)$ \\
\hline & & & & \\
\hline
\end{tabular}

227 SARS-CoV-2 antibody titer

228 Indoor/outdoor patients had the highest mean titer of $197.18 \mathrm{DU} / \mathrm{mL}$, followed by HCWs (163.30

$229 \mathrm{DU} / \mathrm{mL})$ and garment workers $(77.05 \mathrm{DU} / \mathrm{mL})(p<0.001)$. The level (mean) of IgG-spike 230 antibodies in both dosage vaccine recipients was higher $(255.46 \mathrm{DU} / \mathrm{mL})$ than in those who 231 received one $(159.08 \mathrm{DU} / \mathrm{mL})$ or no doses $(53.71 \mathrm{DU} / \mathrm{mL})$ of the vaccine $(p<0.001)$. When the 232 participants had a contact with confirmed cases had a mean titer of $170.89 \mathrm{DU} / \mathrm{mL}$, not known had 233 a titer of $160.05 \mathrm{DU} / \mathrm{mL}$, and in case of noncontact $116.45 \mathrm{DU} / \mathrm{mL}(p<0.001)$. The mean titer of 234 different age groups was statistically significant; nevertheless, we removed this variable from 235 further analysis to minimize the bias due to vaccination strategy followed in Bangladesh (priority 
medRxiv preprint doi: https://doi.org/10.1101/2022.02.09.22270717; this version posted February 9, 2022. The copyright holder for this preprint (which was not certified by peer review) is the author/funder, who has granted medRxiv a license to display the preprint in perpetuity.

It is made available under a CC-BY 4.0 International license.

236 given to aged); details in Table 3. The changes in mean titer of IgG antibody across different time

237 intervals of intervention (one and both doses of vaccination) is illustrated in Figure 2.

Table 3: Univariable analysis (ttest, one way ANOVA) to evaluate the mean difference of quantity of anti-SARS-CoV-2 antibody in serum samples

\begin{tabular}{|c|c|c|c|c|}
\hline Variable & Level & $\begin{array}{l}\text { Mean titer of } \\
\text { IgG }(\mathrm{DU} / \mathrm{ml})\end{array}$ & SD & \begin{tabular}{|l} 
P-value \\
\end{tabular} \\
\hline \multirow[t]{3}{*}{ Doner type } & Health worker & 163.30 & 153.54 & \multirow[t]{3}{*}{$<0.001$} \\
\hline & $\begin{array}{l}\text { Indoor/outdoor } \\
\text { patient }\end{array}$ & 197.18 & 147.04 & \\
\hline & $\begin{array}{l}\text { Garments } \\
\text { worker }\end{array}$ & 77.05 & 115.63 & \\
\hline \multirow[t]{2}{*}{ Gender } & Female & 140.09 & 151.36 & \multirow[t]{2}{*}{0.31} \\
\hline & Male & 151.83 & 148.38 & \\
\hline \multirow[t]{4}{*}{ Age (year) } & 19 to 29 & 106.90 & 132.23 & \multirow[t]{4}{*}{$<0.001$} \\
\hline & 30 to 35 & 151.16 & 157.71 & \\
\hline & 36 to 44 & 160.85 & 143.08 & \\
\hline & 45 to 84 & 176.95 & 155.92 & \\
\hline \multirow[t]{3}{*}{ Vaccination } & No & 53.71 & 91.16 & \multirow[t]{3}{*}{$<0.001$} \\
\hline & Only 1st dose & 159.08 & 161.05 & \\
\hline & Both doses & 255.46 & 117.04 & \\
\hline \multirow{2}{*}{$\begin{array}{l}\text { Days passed after } \\
\text { 1st dose of }\end{array}$} & 31 to 60 days & 131.39 & 152.08 & \multirow[t]{2}{*}{0.10} \\
\hline & 14 to 30 days & 175.10 & \begin{tabular}{|l}
164.09 \\
\end{tabular} & \\
\hline
\end{tabular}




\begin{tabular}{|c|c|c|c|c|}
\hline vaccine & & & & \\
\hline \multirow{3}{*}{$\begin{array}{l}\text { Days passed after } \\
\text { 2nd dose vaccine }\end{array}$} & 120 to 180 days & 147.09 & 119.29 & \multirow[t]{3}{*}{0.02} \\
\hline & 61 to 120 days & 255.82 & 106.00 & \\
\hline & 14 to 60 days & 324.42 & 128.42 & \\
\hline \multirow[t]{2}{*}{ Asymptomatic } & No & 190.01 & 161.93 & $<0.001$ \\
\hline & Yes & 130.03 & 140.19 & \\
\hline \multirow{2}{*}{$\begin{array}{l}\text { Had COVID-19 } \\
\text { confirmed status }\end{array}$} & No & 191.69 & 142.70 & \multirow[t]{2}{*}{0.005} \\
\hline & Yes & 244.87 & 159.74 & \\
\hline \multirow{3}{*}{$\begin{array}{l}\text { Contact with } \\
\text { confirmed case }\end{array}$} & No & 116.45 & 135.21 & \multirow[t]{3}{*}{$<0.001$} \\
\hline & Yes & 170.89 & 154.19 & \\
\hline & Don't know & 160.05 & 158.98 & \\
\hline \multirow{2}{*}{$\begin{array}{l}\text { Taking } \\
\text { immunosuppressi } \\
\text { ve drugs }\end{array}$} & No & 143.02 & 150.09 & \multirow[t]{2}{*}{0.32} \\
\hline & Yes & 181.38 & 152.08 & \\
\hline
\end{tabular}

Figure 2: Evaluation of time effects of vaccines mean difference of quantitative anti-SARS-CoV-2

241 antibody $(\operatorname{IgG})$ in serum samples.

\section{Risk factor analysis}

244 Univariable analysis ( $\chi^{2}$ test, logistic regression) to evaluate the association of different variables

245 with the seroprevalence of anti-SARS-CoV-2 antibody

246 Indoor/outdoor patients amongst the different donor groups had a positivity rate of $81.37 \%(144$

247 of 179) compared to $68.99 \%$ (248 of 362) in the HCWs and 50.56\% in the garments workers (104 
248 of 205); the difference was statistically significant $(p<0.001)$. Both doses of vaccine receivers

249 showed significantly $(p<0.001)$ higher seropositivity than one dose or no vaccine receivers.

250 Similarly, contact with confirmed COVID-19 cases showed a higher odd of being seropositive as

251 compared to noncontact $(p=0.01)[\mathrm{OR}=1.59]$ (Table 4).

252

Table 4: Univariable analysis ( $\chi^{2}$ test, logistic regression) to evaluate the association of different variables with seroprevalence of anti-SARS-CoV-2 antibody

\begin{tabular}{|c|c|c|c|c|c|}
\hline Variable & Level (n) & $\begin{array}{l}\text { Presence of } \\
\text { IgG }\end{array}$ & $\begin{array}{l}\text { TP }(95 \% \\
\text { CI of TP) } \\
* *\end{array}$ & OR & P-value \\
\hline \multirow[t]{3}{*}{ Donor type } & $\begin{array}{l}\text { Health worker } \\
(362)\end{array}$ & 248 & $\begin{array}{l}68.99 \\
(63.8-73.7)\end{array}$ & Ref. & \multirow[t]{3}{*}{$<0.001$} \\
\hline & $\begin{array}{l}\text { Indoor/outdoor } \\
\text { patient (179) }\end{array}$ & 144 & $\begin{array}{l}81.37 \\
(74.7-86.7)\end{array}$ & 1.8 & \\
\hline & $\begin{array}{l}\text { Garments } \\
\text { worker (205) }\end{array}$ & 104 & $\begin{array}{l}50.56 \\
(43.5-57.5)\end{array}$ & 0.47 & \\
\hline \multirow[t]{2}{*}{ Gender } & Female (239) & 151 & $\begin{array}{l}63.47 \\
(56.9-69.5)\end{array}$ & Ref. & \multirow[t]{2}{*}{0.15} \\
\hline & Male (507) & 347 & $\begin{array}{l}68.92 \\
(64.6-72.9)\end{array}$ & 1.26 & \\
\hline Age (year) & 19 to $29(201)$ & 114 & $\begin{array}{l}56.76 \\
(49.5-63.6)\end{array}$ & Ref. & 0.002 \\
\hline
\end{tabular}




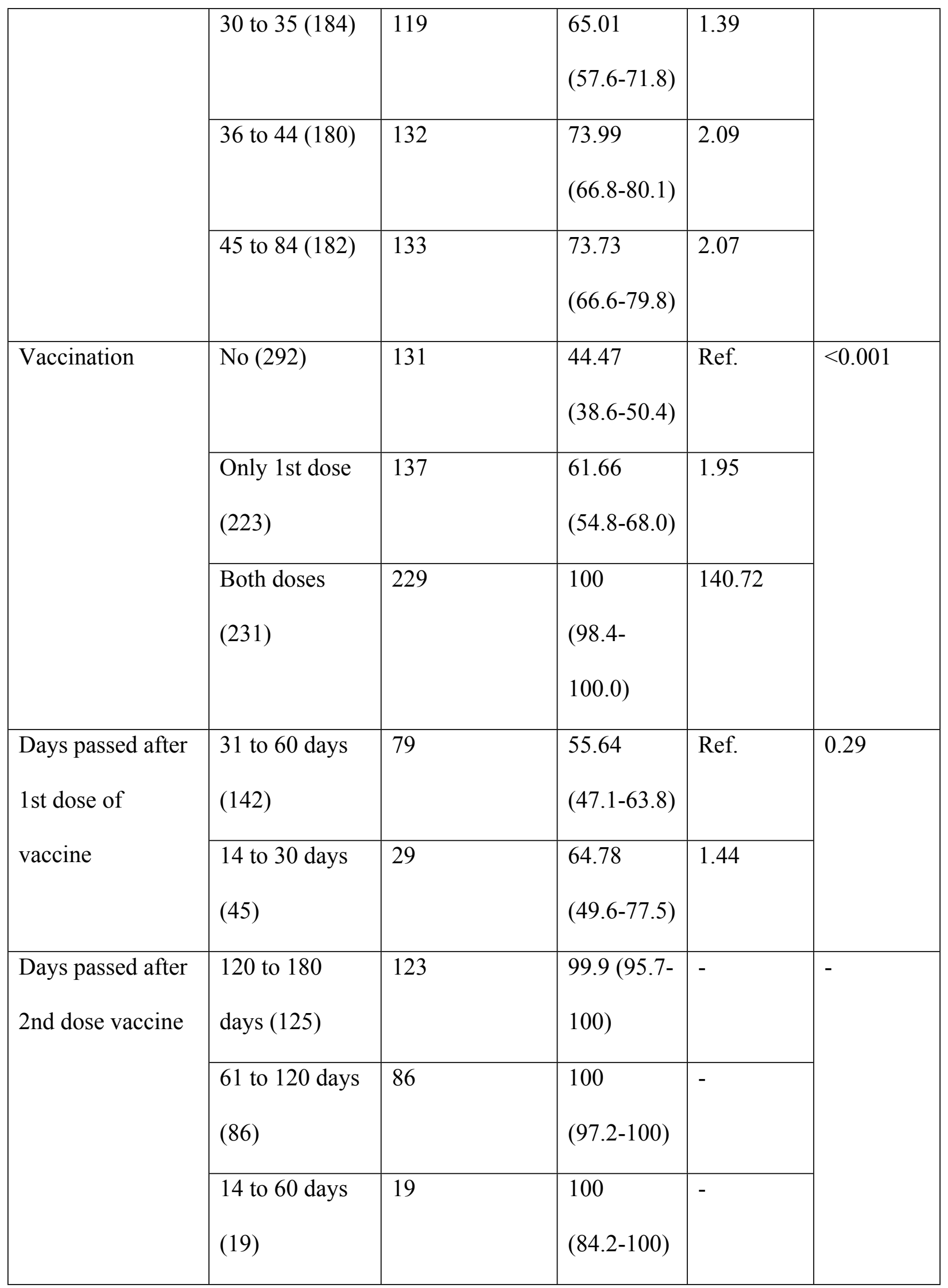




\begin{tabular}{|c|c|c|c|c|c|}
\hline \multirow[t]{2}{*}{ Asymptomatic } & No (220) & 160 & $\begin{array}{l}73.36 \\
(66.9- \\
79.03)\end{array}$ & Ref. & \multirow[t]{2}{*}{0.13} \\
\hline & Yes (528) & 355 & $\begin{array}{l}67.66 \\
(63.4- \\
71.68)\end{array}$ & 0.76 & \\
\hline \multirow[t]{2}{*}{$\begin{array}{l}\text { Had COVID-19 } \\
\text { confirmed status }\end{array}$} & No (144) & 119 & $\begin{array}{l}83.65 \\
(76.3-89.1)\end{array}$ & Ref. & \multirow[t]{2}{*}{0.66} \\
\hline & Yes (113) & 91 & $\begin{array}{l}81.46 \\
(72.9-87.9)\end{array}$ & 0.86 & \\
\hline \multirow[t]{3}{*}{$\begin{array}{l}\text { Contact with } \\
\text { confirmed case }\end{array}$} & No (307) & 187 & $\begin{array}{l}61.11 \\
(55.3-66.6)\end{array}$ & Ref. & \multirow[t]{3}{*}{0.01} \\
\hline & Yes (342) & 244 & $\begin{array}{l}71.93 \\
(66.7-76.6)\end{array}$ & 1.59 & \\
\hline & $\begin{array}{l}\text { Don't know } \\
\text { (76) }\end{array}$ & 49 & $\begin{array}{l}64.81 \\
(53.1-75.0)\end{array}$ & 1.16 & \\
\hline \multirow{2}{*}{$\begin{array}{l}\text { Taking } \\
\text { immunosuppressi } \\
\text { ve drugs }\end{array}$} & No (688) & 447 & $\begin{array}{l}65.32 \\
(61.5-68.9)\end{array}$ & Ref. & \multirow[t]{2}{*}{0.20} \\
\hline & Yes (15) & 12 & $\begin{array}{l}80.91 \\
(54.7-94.3)\end{array}$ & 2.15 & \\
\hline
\end{tabular}

254 Multivariable analysis (logistic regression) to determine the potential factors associated with 255 SARS-CoV-2 antibody-positive status in the study area 
medRxiv preprint doi: https://doi.org/10.1101/2022.02.09.22270717; this version posted February 9, 2022. The copyright holder for this preprint (which was not certified by peer review) is the author/funder, who has granted medRxiv a license to display the preprint in perpetuity.

It is made available under a CC-BY 4.0 International license.

256 The multivariable logistic regression model identified two potential factors that might be 257 influencing the seropositivity of SARS-CoV-2 antibodies in the studied population. The chance of 258 being seropositive was 2.22 times higher in indoor/outdoor patients $(p=0.002)$ and 1.69 times for 259 garments workers than HCWs $(p=0.01)$. Further, both doses of vaccine receivers had a higher chance of being positive $(\mathrm{OR}=174.02)$ than one dose $(\mathrm{OR}=2.34)$ or none dose receivers, and the difference was statistically significant $(p<0.001)$ (Table 5).

Table 5: Output from the final multivariable logistic regression model showing the adjusted effect of potential factors on the seroprevalence of anti-SARS-CoV-2 antibody

\begin{tabular}{|l|l|l|l|l|}
\hline Variable & Level & OR & 95\% CI & P-value \\
\hline Doner type & Health worker & Ref. & & \\
\cline { 2 - 5 } & Indoor/outdoor & 2.22 & $1.33-3.68$ & 0.002 \\
\cline { 2 - 6 } & patient & & & \\
\cline { 2 - 6 } & Garments & 1.69 & $1.09-2.62$ & 0.01 \\
\hline Vaccination & No & & & \\
\cline { 2 - 5 } & Only 1st dose & 2.34 & $1.56-3.50$ & $<0.001$ \\
\cline { 2 - 5 } & Both doses & 174.02 & $41.46-730.40$ & $<0.001$ \\
\hline
\end{tabular}

\section{Discussion}

265 The overall adjusted seroprevalence estimate of SARS-CoV-2 antibodies was 66.99\% (95\% CI: 
medRxiv preprint doi: https://doi.org/10.1101/2022.02.09.22270717; this version posted February 9, 2022. The copyright holder for this preprint (which was not certified by peer review) is the author/funder, who has granted medRxiv a license to display the preprint in perpetuity.

It is made available under a CC-BY 4.0 International license .

of Bangladesh from March to June 2021 [36]. Another research conducted by icddr'b between October 2020 and February 2021 found a lower (55\%) estimate in Chattogram than ours. During the same study period, however, the adjusted seroprevalence in Dhaka, the capital of Bangladesh, was $71 \%$ [37]. Thus, based on several investigations, it can be assumed that seropositivity in Chattogram has been progressively increasing over time. The prevalence might have increased due to either high infection levels or a positive response to the national immunization campaign in its early phases [38]. According to the findings, $68.99 \% \mathrm{HCWs}$ and $81.37 \%$ indoor/outdoor patients were seropositive. Indoor and outdoor patients were more likely than health professionals to be seropositive, possibly due to the combined effect of lack of awareness and knowledge about COVID-19 among some of them and effect of vaccination as they might be were composed of a mixed population of lower to upper socio-economic status and with different educational levels. Tripathi et al., 2020 reported that HCWs were more educated of COVID-19 symptoms, incubation time, problems in high-risk patients, and had greater access to therapy than other residents (non HCWs) [39]. In Navi Mumbai in May 2021, serosurveillance of anti-SARS-Cov-2 antibodies among essential workers revealed that police personnel had a $72 \%$ seropositivity rate, whereas HCWs had a 48\% positivity rate [40]. Moreover, we observed that, among the garment workers, just under $20 \%$ received vaccines and just above $50 \%$ were seropositive, which might have majorly been achieved from natural infections (Figure 1). It might indicate their lack of awareness about disease transmission and vaccination.

We found that the IgG antibody was produced in $61.66 \%$ of the participants who received the first dose of COVID-19 vaccination. This number increased to $100 \%$ among individuals who received a second dose. In a study by Bayram et al., 2021, HCW's' seropositivity rates after the first and second doses of CoronaVac vaccination were found to be $77.8 \%$ and $99.6 \%$, respectively [41]. 
medRxiv preprint doi: https://doi.org/10.1101/2022.02.09.22270717; this version posted February 9, 2022. The copyright holder for this preprint (which was not certified by peer review) is the author/funder, who has granted medRxiv a license to display the preprint in perpetuity.

It is made available under a CC-BY 4.0 International license.

291 Subsequently, when we quantified the antibody titer, we observed it higher in those who received

292 the second dose than in those who received just the first. Detection of highly avid anti-S1/-RBD

293 IgG, independent of the causal mechanism, is seen as a very positive indication and indicator of

294 enhanced humoral immunity [42].

295

296

297

298

299

300

301

302

303

304

305

306

307

308

309

310

311

312

313

Human coronavirus infection may not always result in long-lasting antibody responses, with antibody titers dropping over time [43]. The waning of antibody responses is an essential element to consider while developing a coronavirus vaccine [44]. Our study showed that by the second month following the initial dose, the mean IgG titer in the body had dropped by nearly $25 \%$. However, the antibody's propensity to deteriorate with time was noteworthy. This study revealed that the available mean antibody titers that remained after two months of receiving the second dose had dropped by roughly $21 \%$ by the fourth month, and within the sixth month the mean antibody titer was 147.09 DU/mL. So, it can be assumed that the body still retained considerable antibodies against COVID-19 six months after receiving the second dose vaccine, though the threshold level to prevent the virus is not known.

The underreporting of SARS-CoV-2 infection cases makes it difficult to assess the actual infection burden. Limited testing, flaws in the reporting infrastructure, and a substantial proportion of asymptomatic infections contribute to the underreporting [45]. Asymptomatic carriers spread COVID-19, but the clinical characteristics, viral dynamics, and antibody responses of these individuals are unknown [46]. According to our findings, $67.66 \%$ of the asymptomatic population was seropositive where only $29.03 \%$ of asymptomatic individuals received the first dose of COVID-19 vaccine, and $28.84 \%$ received the second dose too. According to various populationbased studies, a considerable majority of seropositive people were asymptomatic or had no known encounter with a COVID-19 patient [47-49]. Meanwhile, the observation that asymptomatic 
medRxiv preprint doi: https://doi.org/10.1101/2022.02.09.22270717; this version posted February 9, 2022. The copyright holder for this preprint (which was not certified by peer review) is the author/funder, who has granted medRxiv a license to display the preprint in perpetuity.

It is made available under a CC-BY 4.0 International license .

314 people had lower mean IgG levels than symptomatic people back up previous findings that 315 asymptomatic carriers have a lesser humoral immune response to COVID-19 infection [47,50].

316 The study also revealed that people aged above 35 had a greater seroprevalence. Higher 317 seroprevalence among adults could be associated with increased vaccination exposure. On January

31826 of this year, the government began accepting registrations for the COVID-19 vaccine for 319 persons aged 55 and up in the country [51]. In the second phase, the age limit was dropped to 40 320 years or more, and vaccination of youngsters aged 12-17 has recently begun in the country [52].

321 The latest and more deadly SARS-CoV-2 viral strains, as well as the possibility of losing immunity 322 with time after vaccination, have prompted health professionals to consider the need for boosters. 323 Research on threshold titers giving protection and time intervals of declining immunity post324 immunization for low-middle-income nations like Bangladesh are essential before launching 325 further booster doses. An important application of serological tests is to determine the antibody responses generated upon SARS-CoV-2 infection and vaccination [53]. The continuation of this

327 study on those who received the second dose more than six months ago will provide an appropriate 328 booster interval, risk population category, and overview of herd immunity. According to a recent 329 study conducted in the greater Chattogram division it is evident that administering the first dose 330 (Oxford-AstraZeneca) vaccine significantly reduces health risk during the COVID-19 infection 331 phase [54]. So, it is evident that similar research is clamoring for justifications for booster 332 administration. Additionally, more research is required to assess the efficacy of booster doses. 333 Government and healthcare professionals must adopt COVID-19 vaccine booster dose utilization 334 guidelines that consider the risks of fading immunity, new virus strains, and prioritizing vulnerable 335 groups. 
medRxiv preprint doi: https://doi.org/10.1101/2022.02.09.22270717; this version posted February 9, 2022. The copyright holder for this preprint (which was not certified by peer review) is the author/funder, who has granted medRxiv a license to display the preprint in perpetuity.

It is made available under a CC-BY 4.0 International license .

Our study has several limitations, such as the fact that we only collected samples from hospitals and the garment industry, but the results would be more representative of the community if we included other groups. We could not compare immunological responses produced by different COVID-19 vaccine brands at the same post-vaccination interval since distinct COVID-19 vaccines were licensed and supplied to CMA at different times. We did not reveal the type and name of COVID-19 vaccines, whereas a sufficient fraction was not covered under the vaccination program, and we were concerned about an infodemic.

\section{Acknowledgment}

The authors acknowledge Bangladesh Institute of Tropical and Infectious Diseases (BITID), Chattogram General Hospital, Chittagong Medical University, Medical Center (Pvt.), Imperial Hospital Limited, Chattogram Asian Apparels Limited, Clifton Garments Limited, Bangladesh Garment Manufacturers and Exporters Association (BGMEA) Chattogram, and BGMEA Hospital and Diagnostic Center for providing samples and administrative support. The laboratory facilities were supported by the Dept. of Pathology and Parasitology, CVASU. The authors sincerely acknowledge the One Health Institute, CVASU for logistic support.

\section{Conflict of interest}

The authors have no potential conflict of interest.

\section{Authors Contribution}

JA: Conceptualization, methodology, project proposal writing, administration, data curation, writing-original draft, review and editing. MSI: Conceptualization, methodology, project 
359 administration, laboratory tasks, data visualization, writing-original draft, review and editing.

360 MTUQ: Sample collection, data curation. AD: Sample collection, data curation. FMYH:

361 Laboratory tasks. MSI: Sample collection, data curation. TR: Sample collection, data curation.

362 SD: Data curation, writing review and editing. MAHC: Conceptualization, investigation,

363 methodology, supervision, and reviewing-final manuscript. GBD: Project investigation, fund

364 acquisition, and reviewing-final manuscript. SC: Conceptualization, investigation, methodology,

365 supervision, data- validation, analysis, visualization, writing-original draft, and reviewing-final

366 manuscript.

367

\section{Funding Information}

369 The study was funded by the Director of Research \& Extension, CVASU.

$371 \quad$ References

372 1. Rana EA, Chowdhury NS, Islam MS, Ara J, Nasrin SS, Dutta P, Bristi SZ, Nizami TA,

373 Chakraborty P, Siddiki AZ. Molecular detection and prevalence of SARS-CoV-2 during the

374 early outbreak in southern Bangladesh. International Journal of One Health. 2020;6(2):153-9.

375 2. Dhaka Tribune, First Coronavirus Case Confirmed in Chittagong, 6 Buildings in Lockdown.

3762020 April 3. [Internet]. Available from:

377 https://archive.dhakatribune.com/bangladesh/nation/2020/04/03/covid-19-first-case-confirmed-

378 in-chittagong 
medRxiv preprint doi: https://doi.org/10.1101/2022.02.09.22270717; this version posted February 9, 2022. The copyright holder for this preprint (which was not certified by peer review) is the author/funder, who has granted medRxiv a license to display the preprint in perpetuity.

It is made available under a CC-BY 4.0 International license .

9. Gomes LR, Durans AM, Napoleão-Pêgo P, Waterman JA, Freitas MS, De Sá NB, Pereira

3. Dhaka Tribune, Another Corona Virus Patient Dies in Chittagong. 2020 April 13. [Internet]. Available from: https://www.dhakatribune.com/health/coronavirus/2020/04/13/anothercoronavirus-patient-dies-in-chittagong

4. Goenka MK, Afzalpurkar S, Goenka U, Das SS, Mukherjee M, Jajodia S, Shah BB, Patil VU, Rodge G, Khan U, Bandyopadhyay S. Seroprevalence of COVID-19 amongst health care workers in a tertiary care hospital of a metropolitan city from India.

5. Vernet R, Charrier E, Grogg J, Mach N. A Quantitative ELISA Protocol for Detection of Specific Human IgG against the SARS-CoV-2 Spike Protein. Vaccines. 2021 Jul;9(7):770.

6. Bryant JE, Azman AS, Ferrari MJ, Arnold BF, Boni MF, Boum Y, Hayford K, Luquero FJ, Mina MJ, Rodriguez-Barraquer I, Wu JT. Serology for SARS-CoV-2: Apprehensions, opportunities, and the path forward. Science immunology. 2020 May 19;5(47):eabc6347.

7. Shakiba M, Nazemipour M, Salari A, Mehrabian F, Nazari SS, Rezvani SM, Ghasempour Z, Heidarzadeh A, Mansournia MA. Seroprevalence of SARS-CoV-2 in Guilan Province, Iran, April 2020. Emerging infectious diseases. 2021 Feb;27(2):636.

8. Bendavid E, Mulaney B, Sood N, Shah S, Bromley-Dulfano R, Lai C, Weissberg Z, Saavedra-Walker R, Tedrow J, Bogan A, Kupiec T. Covid-19 antibody seroprevalence in santa clara county, california. International journal of epidemiology. 2021 Apr;50(2):410-9.

LV, Furtado JS, Aquino RG, Machado MC, Fintelman-Rodrigues N. Multiepitope Proteins for 
medRxiv preprint doi: https://doi.org/10.1101/2022.02.09.22270717; this version posted February 9, 2022. The copyright holder for this preprint (which was not certified by peer review) is the author/funder, who has granted medRxiv a license to display the preprint in perpetuity.

It is made available under a CC-BY 4.0 International license.

398 the Differential Detection of IgG Antibodies against RBD of the Spike Protein and Non-RBD

399 Regions of SARS-CoV-2. Vaccines. 2021 Sep;9(9):986.

400 10. Freeman B, Lester S, Mills L, Rasheed MA, Moye S, Abiona O, Hutchinson GB, Morales-

401 Betoulle M, Krapinunaya I, Gibbons A, Chiang CF. Validation of a SARS-CoV-2 spike protein

402 ELISA for use in contact investigations and serosurveillance. Biorxiv. 2020 Jan 1.

403 11. Brown TS, Walensky RP. Serosurveillance and the COVID-19 epidemic in the US:

404 undetected, uncertain, and out of control. Jama. 2020 Aug 25;324(8):749-51.

405 12. Hossain M, Das SC, Raza MT, Ahmed IU, Eva IJ, Karim T, Chakraborty P, Gupta SD.

406 Immediate and post-COVID complications of symptomatic and asymptomatic COVID-19

407 patients in Bangladesh: a cross-sectional retrospective study. Asian Journal of Medical and

408 Biological Research. 2021 Jun 30;7(2):191-201.

409 13. Thomas SN, Altawallbeh G, Zaun CP, Pape KA, Peters JM, Titcombe PJ, Dileepan T, Rapp

410 MJ, Bold TD, Schacker TW, Arbefeville S. Initial determination of COVID-19 seroprevalence

411 among outpatients and healthcare workers in Minnesota using a novel SARS-CoV-2 total

412 antibody ELISA. Clinical Biochemistry. 2021 Apr 1;90:15-22.

413 14. Lerner AM, Eisinger RW, Lowy DR, Petersen LR, Humes R, Hepburn M, Cassetti MC. The

414 COVID-19 serology studies workshop: recommendations and challenges. Immunity. 2020 Jul

$41514 ; 53(1): 1-5$. 
medRxiv preprint doi: https://doi.org/10.1101/2022.02.09.22270717; this version posted February 9, 2022. The copyright holder for this preprint (which was not certified by peer review) is the author/funder, who has granted medRxiv a license to display the preprint in perpetuity.

It is made available under a CC-BY 4.0 International license .

15. Wang H, Wiredja D, Yang L, Bulterys PL, Costales C, Röltgen K, Manalac J, Yee J,

417 Zehnder J, Shi RZ, Boyd SD. Case-Control Study of Individuals with Discrepant Nucleocapsid

418 and Spike Protein SARS-CoV-2 IgG Results. Clinical Chemistry. 2021 Mar 15.

419 16. Gudbjartsson DF, Norddahl GL, Melsted P, Gunnarsdottir K, Holm H, Eythorsson E,

420 Arnthorsson AO, Helgason D, Bjarnadottir K, Ingvarsson RF, Thorsteinsdottir B. Humoral

421 immune response to SARS-CoV-2 in Iceland. New England Journal of Medicine. 2020 Oct

$422 \quad 29 ; 383(18): 1724-34$.

423 17. Aljazeera, Coronavirus Pandemic, Bangladesh Starts COVID Vaccination Drive. 2021 Jan

424 28. [Internet]. Available from: https:/www.aljazeera.com/news/2021/1/28/bangladesh-starts-

425 covid-vaccination-drive

426

427 18. Anadolu Agency, World, Asia-Pacific, Latest on CoronavirusOutbreak, Bangladesh Starts

428 Nationwide COVID Vaccination Drive. 2021 Feb 7. [Internet]. Available from:

429 https://www.aa.com.tr/en/asia-pacific/bangladesh-starts-nationwide-covid-vaccination-

430 drive $/ 2136643$

431 19. COVID-19 Vaccination Dashboard for Bangladesh, Health Emergency Control Center,

432 DHIS2, Surokkha App, 2022. [Internet]. Available from:

433 http://103.247.238.92/webportal/pages/covid19-vaccination-update.php

434 20. Dhaka Tribune, Bangladesh Begins Booster Vaccination. 2021 Nov 28. [Internet]. Available

435 from: https://newsarchive.app/a/dhakatribune/2021/11/28/Bangladesh-begins-booster-

436 vaccination 
437 21. Mahmud S, Mohsin M, Khan IA, Mian AU, Zaman MA. Knowledge, beliefs, attitudes and 438 perceived risk about COVID-19 vaccine and determinants of COVID-19 vaccine acceptance in 439 Bangladesh. PloS one. 2021 Sep 9;16(9): e0257096.

442 workers worldwide from COVID-19: a systematic review. BMJ global health. 2020 Dec

443 1;5(12):e003097. Staff (COVID 19+) From 08/03/2020 till today on 28/09/2021. [Internet]. Available from: https://bma.org.bd/covid-19/Total\%20Affected\%20Doctor,\%20Nurse\%20\&\%20Staff.pdf

447 24. Chen Q, Liang M, Li Y, Guo J, Fei D, Wang L, He LI, Sheng C, Cai Y, Li X, Wang J. 448 Mental health care for medical staff in China during the COVID-19 outbreak. The Lancet 449 Psychiatry. 2020 Apr 1;7(4): e15-6.

451 workers: a rapid review. Safety and health at work. 2020 Sep 1;11(3):262-5.

452 26. Iversen K, Bundgaard H, Hasselbalch RB, Kristensen JH, Nielsen PB, Pries-Heje M,

453 Knudsen AD, Christensen CE, Fogh K, Norsk JB, Andersen O. Risk of COVID-19 in health-care 454 workers in Denmark: an observational cohort study. The Lancet Infectious Diseases. 2020 Dec $455 \quad 1 ; 20(12): 1401-8$. 
medRxiv preprint doi: https://doi.org/10.1101/2022.02.09.22270717; this version posted February 9, 2022. The copyright holder for this preprint (which was not certified by peer review) is the author/funder, who has granted medRxiv a license to display the preprint in perpetuity.

It is made available under a CC-BY 4.0 International license.

456

457

458

459

460

461

462

463

464

465

466

467

468

469

470

471 Global Health. 2020 Nov 1;8(11): e1368.

472 34. Islam MS, Hasib FY, Nath C, Ara J, Nu MS, Fazal MA, Chowdhury S. Coronavirus disease 4732019 and its potential animal reservoirs: A review. Health. 2021 Jul 1;7(2):171-81.

27. Ehrlich H, McKenney M, Elkbuli A. Protecting our healthcare workers during the COVID19 pandemic. The American journal of emergency medicine. 2020 Jul 1;38(7):1527-8.

28. Shaw A, Flott K, Fontana G, Durkin M, Darzi A. No patient safety without health worker safety. The Lancet. 2020 Nov 14;396(10262):1541-3.

29. Kontoangelos K, Economou M, Papageorgiou C. Mental health effects of COVID-19

pandemia: a review of clinical and psychological traits. Psychiatry investigation. 2020

Jun;17(6):491.

30. Khan AN, Ullah MR. Export scenario between Bangladesh and China: Opportunities of Bangladesh in RMG Sector. Eur Sci J. 2017;13(28):299-320.

31. Hosen MS, Nafiujjaman M, Biswas FN. Garment employees are at higher risk than any other workers in COVID-19 pandemic in Bangladesh. Caspian Journal of Health Research. 2020 Jan $10 ; 5(1): 1-2$.

32. Dyal JW. COVID-19 among workers in meat and poultry processing facilities-19 states, April 2020. MMWR. Morbidity and mortality weekly report. 2020;69.

33. Marinaccio A, Guerra R, Iavicoli S. Work a key determinant in COVID-19 risk. The Lancet 34. Islam MS, Hasib FY, Nath C, Ara J, Nu MS, Fazal MA, Chowdhury S. Coronavirus disease 
medRxiv preprint doi: https://doi.org/10.1101/2022.02.09.22270717; this version posted February 9, 2022. The copyright holder for this preprint (which was not certified by peer review) is the author/funder, who has granted medRxiv a license to display the preprint in perpetuity.

It is made available under a CC-BY 4.0 International license .

474 35. World Health Organization, Population-Based Age-Stratified Seroepidemiological

475 Investigation Protocol for Coronavirus 2019 (COVID-19) Infection. 2020 May. [Internet].

476 Available from: https:/www.who.int/publications/i/item/WHO-2019-nCoV-Seroepidemiology-

$477 \quad 2020.2$

478 36. Bhuiyan TR, Hulse JD, Hegde S, Akhtar M, Islam T, Khan ZH, Khan II, Rashid M, Rashid

479 R, Shirin T, Gurley ES. SARS-CoV-2 seroprevalence in Chattogram, Bangladesh before a

480 National Lockdown, March-April 2021. medRxiv. 2021 Jan 1.

481 37. icddr,b, news, Higher COVID-19 Seropositivity Observed Among Residents in Dhaka and

482 Chattogram. 2021 June 22. [Internet]. Available from: https://www.icddrb.org/news-and-

483 events/news?id=878

484 38. Ward H, Cooke G, Whitaker M, Redd R, Eales O, Brown JC, Collet K, Cooper E, Daunt A,

485 Jones K, Moshe M. REACT-2 Round 5: increasing prevalence of SARS-CoV-2 antibodies

486 demonstrate impact of the second wave and of vaccine roll-out in England. MedRxiv. 2021 Jan

4871.

488 39. Tripathi R, Alqahtani SS, Albarraq AA, Meraya AM, Tripathi P, Banji D, Alshahrani S,

489 Ahsan W, Alnakhli FM. Awareness and preparedness of COVID-19 outbreak among healthcare

490 workers and other residents of South-West Saudi Arabia: a cross-sectional survey. Frontiers in

491 Public Health. 2020 Aug 18;8:482.

492 40. Maheshwari U, Sahai J, Hebbar V. Serosurveillance of Anti SARS-Cov-2 Antibodies among

493 Essential Workers in Navi Mumbai-A Single Centre Study. International Journal of Health

494 Sciences and Research. 2021;11(7):99-104. 
medRxiv preprint doi: https://doi.org/10.1101/2022.02.09.22270717; this version posted February 9, 2022. The copyright holder for this preprint (which was not certified by peer review) is the author/funder, who has granted medRxiv a license to display the preprint in perpetuity.

It is made available under a CC-BY 4.0 International license .

497 of medical virology. 2021 May 21

498

499

500

501

502

503

504 Frontiers in Medicine. 2021;8.

47. Alkurt G, Murt A, Aydin Z, Tatli O, Agaoglu NB, Irvem A, Aydin M, Karaali R, Gunes M,

512 Yesilyurt B, Turkez H. Seroprevalence of coronavirus disease 2019 (COVID-19) among health

513 care workers from three pandemic hospitals of Turkey. PloS one. 2021 Mar 3;16(3): e0247865.

41. Bayram A, Demirbakan H, Karadeniz PG, Erdoğan M, Koçer I. Quantitation of antibodies

42. Neumann F, Rose R, Römpke J, Grobe O, Lorentz T, Fickenscher H, Krumbholz A.

Development of SARS-CoV-2 specific IgG and virus-neutralizing antibodies after infection with variants of concern or vaccination. Vaccines. $2021 \mathrm{Jul} ; 9(7): 700$.

44. Amanat F, Krammer F. SARS-CoV-2 vaccines: status report. Immunity. 2020 Apr $14 ; 52(4): 583-9$.

45. Bhattacharyya R, Kundu R, Bhaduri R, Ray D, Beesley LJ, Salvatore M, Mukherjee B.

Incorporating false negative tests in epidemiological models for SARS-CoV-2 transmission and reconciling with seroprevalence estimates. Scientific reports. 2021 May 7;11(1):1-4.

46. Xiao T, Wang Y, Yuan J, Ye H, Wei L, Liao X, Wang H, Qian S, Wang Z, Liu L, Zhang Z. Early viral clearance and antibody kinetics of COVID-19 among asymptomatic carriers. 
medRxiv preprint doi: https://doi.org/10.1101/2022.02.09.22270717; this version posted February 9, 2022. The copyright holder for this preprint (which was not certified by peer review) is the author/funder, who has granted medRxiv a license to display the preprint in perpetuity.

It is made available under a CC-BY 4.0 International license.

514 48. Mukhtar A, Alfishawy M, Alkhatib E, Hosny M, Ollaek M, Elsayed A, Salem MR, Ghaith

515

D. Asymptomatic SARS-CoV-2 infection among healthcare workers in a non-COVID-19

516 teaching university hospital. Journal of Public Health Research. 2021 Jun 24;10(3).

517 49. Selvaraju S, Kumar MS, Thangaraj JW, Bhatnagar T, Saravanakumar V, Kumar CP, Sekar

518 K, Ilayaperumal E, Sabarinathan R, Jagadeesan M, Hemalatha MS. Population-based serosurvey

519 for severe acute respiratory syndrome coronavirus 2 transmission, Chennai, India. Emerging

520 Infectious Diseases. 2021 Feb;27(2):586.

521 50. Long QX, Tang XJ, Shi QL, Li Q, Deng HJ, Yuan J, Hu JL, Xu W, Zhang Y, Lv FJ, Su K.

522 Clinical and immunological assessment of asymptomatic SARS-CoV-2 infections. Nature

523 medicine. 2020 Aug;26(8):1200-4.

524 51. Dhaka Tribune, Bangladesh Lowers Covid-19 Vaccine Age Limit to 18 Years. 2021 Oct 20.

525 [Internet]. Available from: https://www.dhakatribune.com/bangladesh/2021/10/20/bangladesh-

526 lowers-covid-19-vaccine-age-limit-to-18-years

527 52. Dhaka Tribune, COVID Vaccination Campaign for School Students. 2021 Nov 1. [Internet].

528 Available from: https:/www.dhakatribune.com/bangladesh/2021/11/01/covid-vaccination-

529 campaign-for-school-students-kicks-off

530 53. Krammer F, Simon V. Serology assays to manage COVID-19. Science. 2020 Jun

531 5;368(6495):1060-1. 
medRxiv preprint doi: https://doi.org/10.1101/2022.02.09.22270717; this version posted February 9, 2022. The copyright holder for this preprint (which was not certified by peer review) is the author/funder, who has granted medRxiv a license to display the preprint in perpetuity.

532 54. Rana EA, Dutta P, Islam MS, Nizami TA, Das T, Chowdhury S, Das GB. Severity

533 assessment of single dose Oxford-AstraZeneca vaccinated individuals infected with SARS CoV-

5342 in the Southeast Bangladesh. medRxiv. 2021 Jan 1. 


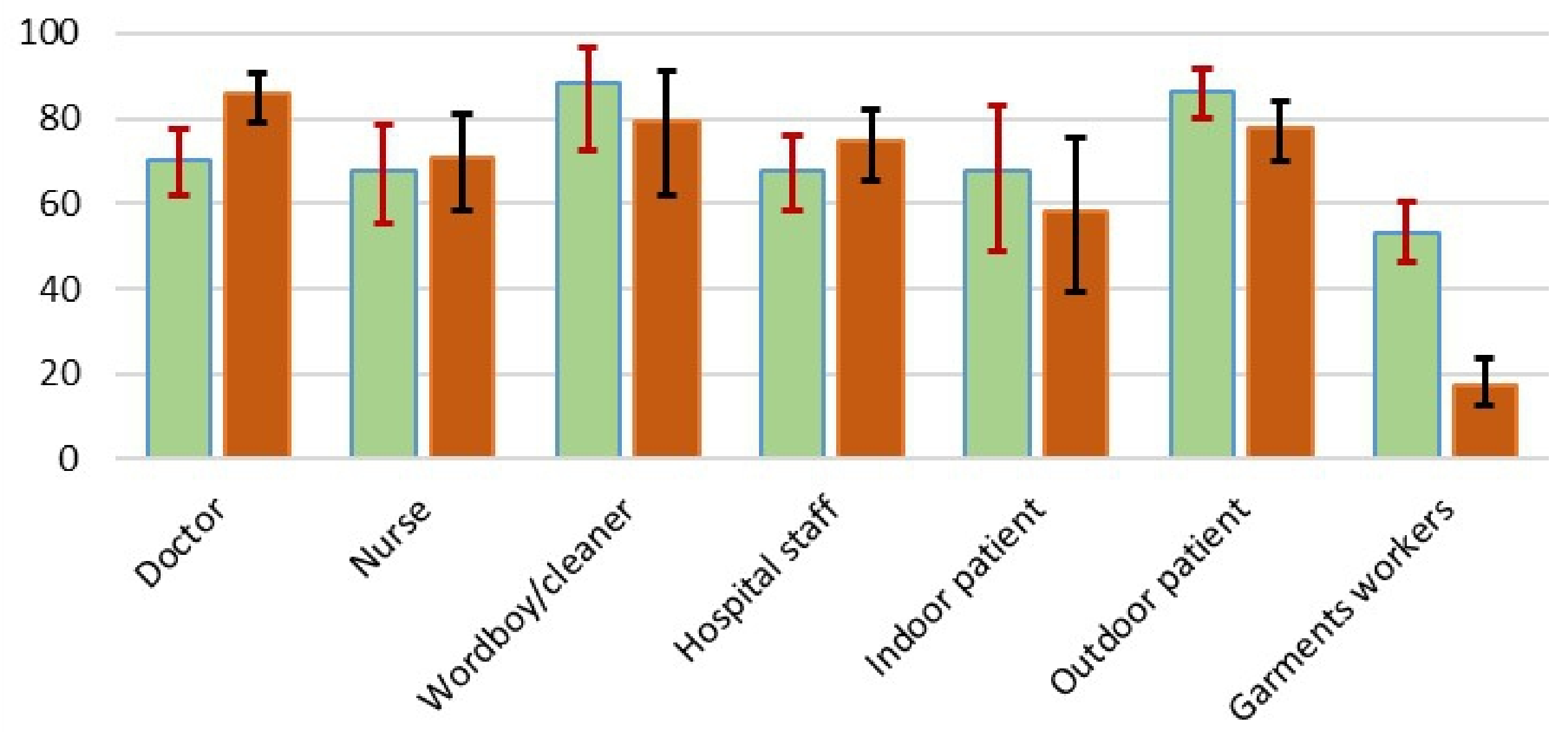

$\square$ Prevalence of IgG $\quad$ Percent vaccinated

Figure 1 


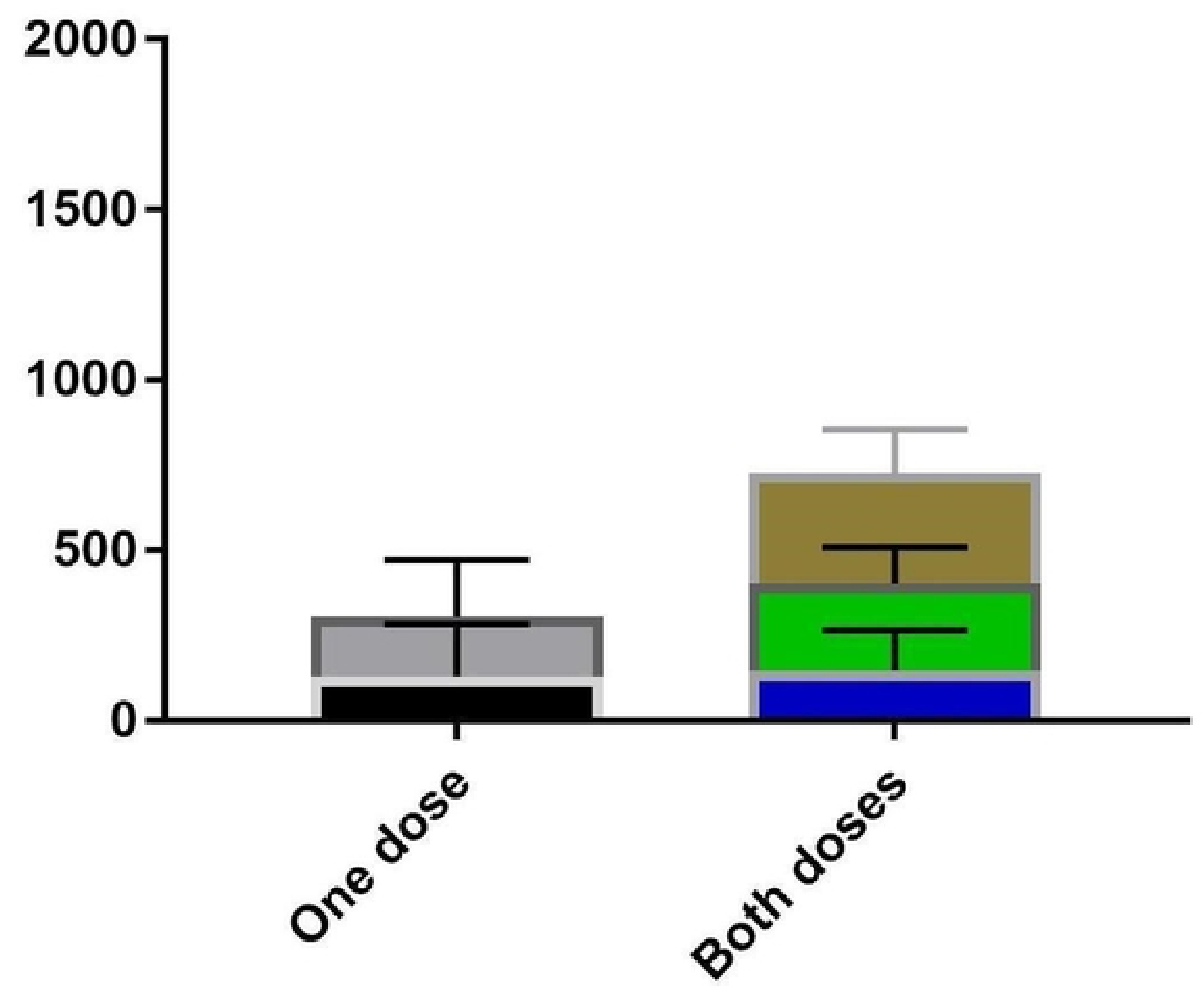

-14-60 days

- 61-120 days

- 120-180 days

ㅁ 14-30 days

- 31-60 days

Mean titer of IgG and SD

Figure 2 